\title{
IMPROVEMENT OF COMMUNICATION SKILL FOR MILLENNIALS ACCOUNTANT
}

\author{
Erna SETIANY ${ }^{1}$, Nurul HIDAYAH ${ }^{* *}$, and Anees Janee ALI ${ }^{3}$ \\ 1,2Universitas Mercu Buana \\ ${ }^{3}$ University Sains Malaysia \\ nurul.hidayah@mercubuana.ac.id
}

\begin{abstract}
The purpose of implementing this community service program is to improve the ability of prospective professional accountants to communicate well. Through this effort their communication skills and professionalism can be improved. Thus, this community service program can be seen as an effort to improving the ability of millennials accountant to hone their communication skills in a professional manner. Millennial career expectations can be seen as a system of norms, values, and beliefs (Suchman, 1995) which characterize members of this new generation of accountants. Millennials do not have as much loyalty as the previous generation. This cannot be ignored by accounting companies when they compete to recruit good candidates. Therefore, becomes important to discuss improving communication skills for accounting students so that they can overcome the obstacles of communication as accountant professionals. Outreach targets in the community service program that will be carried out within the Mercu Buana University for these accountant millennials are millennials accountants get knowledge about how to communicate professionally, and millennials accountants can develop themselves professionally in order to achieve career success as accountants. The implementation of the Community Service Program will be held around June 5-15, 2019 by involving the PPM Team and assisted by Students. Activities will be carried out Universitas Mercu Buana. The types of activities carried out were in the form of seminars and explained the material on how to improve the communication skills of millennial accountants.
\end{abstract}

Keyword: Millennial Accountant, Community Service, Communication Skill, Accountant Professional.

\section{BACKGROUND}

The workforce currently consists of individuals from four different generations: Silent Generation (born 1925-1945), Baby Boomers (born 1946-1964), Generation X (born 1965-81), and Millennials (born 1982-1999) (Twenge, Campbell, Hoffman, \& Lance, 2010), several other researchers have different opinions about the range of years, but agreeing with the concept of the four generations is Foot and Stoffman (1996), Ng et al. (2010). The term 'generation' is traditionally used to refer to a group of people born and living during the same period of time, which usually spans 15 years. With four different generations making up today's workforce, it can be difficult understanding what they all need and where they are best utilised. Each group brings a different dynamic to the table, but the only way to truly harness their potential is to understand their generational characteristics.

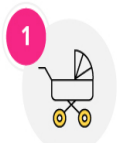
(bom 1946-1964)
BABY BOOMERS

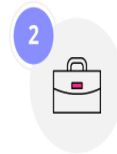

GENX

(born 1965-1979

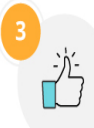

MILLENNIALS/GEN Y (born 1977-1994)

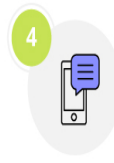

GEN Z
Boomers are characterised as being workaholics who relish long weeks and overtime. They are more committed to their roles than any other generation. Baby boomers are considered good team players, with 53 per cent of organisations saying they work well with others. The professionals in this generation are regarded as making excellent mentors to their colleagues and juniors in the organisation. While the Gen X majority of organisations (70 per cent) believe Gen X are the best overall workers. These professionals are committed to juggling work with family time, and favour work-life balance in an organisation.Gen $\mathrm{X}$ is considered to be the biggest revenue generators overall. Of all generations currently featuring in the workforce.

Millennials are considered the most independent workers, millennials are concerned with ethics and the social responsibility of the organisation they work for Millennials have grown up sourcing information, they need to be left to create their own processes rather than being told exactly what to do. How the Gen Z ? They most technology competent of any generation, members of Gen $\mathrm{Z}$ are able to pick up new developments quicker than other employees. This generation is particularly ambitious, with two-thirds of Gen $\mathrm{Z}$ saying their goal in life is to make it to the top of their profession. Gen $Z$ are natural entrepreneurs, with 72 percent wanting to start their own business and hire people.Described as the 'always on' generation, Gen $\mathrm{Z}$ are able to multitask unlike any other generation, using up to five screens at once. Each generation brings something uniquely valuable to the workforce. By understanding what they have to offer, we can identify key training and development opportunities that will align with their unique strengths. It will also help to gauge where skills gaps may lie so that can prioritise filling them. Read more about the ways in which firm can assess employee needs and implement development strategies. Like accounting firms also face cross-generation workforce. Millennials have hope in terms of worklife balance, pay and benefits, prospects for progress, work experience and work environment ( $\mathrm{Ng}$ et al., 2010). This cannot be ignored by accounting companies when they compete to recruit good candidates.

Millennial career expectations can be seen as a system of norms, values, and beliefs (Suchman, 1995) which characterize members of this new generation of 
accountants. Millennials do not have as much loyalty as the previous generation. They are ready to quit their jobs if they don't get what they want $(\mathrm{Ng}$, Schweitzer, \& Lyons, 2010; Petroulas, Brown, \& Sundin, 2010).

Howe and Strauss described the Millennials as having seven distinguishing traits. Only time will tell if Millennials' persona will evolve from the following: 1 .

Millennials are special, vital, and full of promise, not only for themselves, but also for the future of our society and world. 2. They are sheltered, having been smothered with safety rules and devices. 3 . They are confident as a result of their trust and optimism. 4. They are teamoriented, having been raised on sports teams and group learning. 5. They are achieving, the result of higher school standards and an instilled sense of accountability. 6 . They are pressured and feel the need to excel and do well. 7. They are conventional, father than rebellious. Howe and Strauss' description of Millennials acts as a one reference point for the current study; although, the empirical research summarized below addresses generational differences topics more salient within the context of work.

More specifically, Hartman \& Cambridge (2011) notes that key characteristics of today's undergraduate and graduate students, provide evidence of the importance of effective communication skills for both individual and organizational success, and offer several recommendations for how to improve millennials' communication skills. They believe that educating students about the concepts of style-typing and styleflexing will help them become more effective communicators by deepening their understanding of the communication process. The same thing happened to accountants and accounting under graduates and graduates. Therefore, becomes important to discuss improving communication skills for accounting students so that they can overcome the obstacles of communication as accountant professionals.

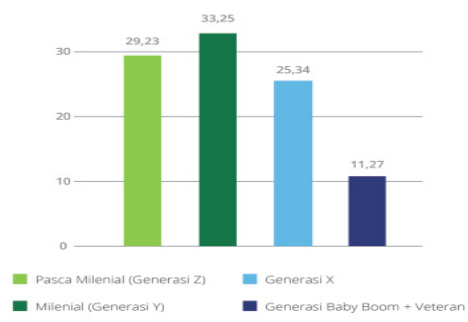

Figure 1 Population composition by gender

Hartman \& Cambridge (2011) summed up common perceptions about millennial generation include the following:

1. They need feedback and praise.

2. They often change jobs which can cause employers to question millennials' loyalty, and reduce the desire of entrepreneurs to want to invest in it. Only one fifth of the millennium generation anticipates that they will continue to work for more than 5 years (Robert Half International, 2008).

3. They are overconfident, argue, and hope to be heard (Alsop, 2007).
4. They believe that they do not have to climb the career ladder when they enter an organization.

5. They are uncomfortable with criticism and can be aggressive and even spicy when criticized (Tyler, 2008).

6. They enjoy the structure and do not like ambiguity.

7. They prefer clear rules, clear policies, and responsibilities.

8. They see themselves as indispensable beings with high hopes and desires to be sought (Alsop, 2006).

All of these problems require a solution. Prospective professional accountants need training to develop communication skills that can help them enter the workforce. The accounting sector of the finance industry faces a dilemma moving forward as baby boomers retire and the millennial generation replaces them. Young accountants have different needs than those of their parents, and hiring managers at accounting firms have a challenging problem to solve. Plenty of people attend college to be accountants, but companies may not step up to give millennials what they want in a job situation.

\section{Solution And Outcome Target}

To overcome the problem of communication millennials accountan activities need to be carried out to provide information to them, how to communicate well and display professionalism. Through training, it is expected that millennials accountants can develop themselves into professionals and can become successful professionals in the accounting field. The information will hopefully help firm keep young accountants interested and engaged. Communication remains the best way to bridge any generational issues between the head of a firm and any young accountants starting fresh out of college. People who have been in the business 30 years need to understand that the millennial generation represents a unique demographic position in American society. These people rely more on technology, love to innovate and have different skill sets than accountants who went to school in the 1980s and 1990s.

Managers at accounting companies should remember their first day on the job and the 10 million questions they had as young accountants. Newcomers, when they first started, wanted their desires, wants and goals to be heard and understood. Millennials remain the same way. Graduates just out of college have their own aspirations and they want new bosses to keep open lines of communication. Millennials want instant feedback that works both ways, and they want bosses who explain why things work at an office and understand the need for a work-life balance.

Millennials want to be challenged and get paid what they're worth. Lack of salary and small opportunities for advancement represent two main issues this younger generation cites as reasons to move on to another job. Accounting firms must communicate, up front, that if you become a rock star at the office, and might be rewarded. 
Otherwise, high-energy candidates may go elsewhere, and the company with the initial hire loses out completely. Young accountants have more opportunities now than they would have had 20 years ago. Technology and growth in American businesses. The Big Four accounting firms, Pricewaterhouse Coopers, Ernst \& Young, Deloitte and KPMG, all represent great places to start an accounting path. However, millennials may not stay with those companies for an entire career as they would have in years past. After cutting their teeth for five to 10 years, younger people may want to head the finance departments of other firms as a career

To solve the problem, we must understand the concept of communication. Communication is a foundational item in every aspect of our day-to-day lives. Yet, it is an aspect that we tend to take for granted especially in the business world. The companies have to understand and leverage their millennial talent while also helping millennials develop the communication and leadership skills necessary to one day lead the business world, there tends to be a massive generational divide on communication. However, the people who have the ability to effectively communicate across generational lines can cut through any perceived differences and achieve success. Outreach targets in the community service program that will be carried out for these accountant millennials are:

1. Millennials accountants get knowledge about how to communicate professionally.

2. Millennials accountants can develop themselves professionally in order to achieve career success as accountants.

The Goals of implementing this community service program is to improve the ability of prospective professional accountants to communicate well. Through this effort their communication skills and professionalism can be improved. Thus, this community service program can ce seen as an effort to improving the ability of millennials accountant to hone their communication skills in a professional manner.

\section{METHOD}

The purpose of this community service program is as a manifestation of the Tri Dharma of UMB Higher Education in order to provide knowledge and foster professional young people.

The benefits of the Community Service Program activities are:

a. Provide assistance in thinking, energy, science in planning the development of accounting communications millennials.

b. Providing ideas for changes in communication styles to be able to showcase the professional characteristics in millennial accountants ...

c. Provide input and solutions to the problems faced by the family in terms of professional communication.
The aim of this community service activity is to help millennial accountants to develop communication skills. In this case the target is students and accounting graduates who are ready to enter the workforce as professional accountants.

The types of activities carried out were in the form of seminars and explained the material on how to improve the communication skills of millennial accountants.

Location and Place Community empowerment activities involving PPM students are conducted at Mercu Buana University. The activity is carried out from November 2018. Materials and Materials used are literature media, fliyer, social media, and power point.

Implementation Method The initial stage is to analyze the situation and problems faced by millennial accountants. Seminar and counseling methods. The method of activities carried out is basically a participatory method and actions involving millennial accountants in this activity. The material at the time of counseling, training, and assistance was provided through learning between theory and demonstration.

\section{RESULT AND DISCUSSION}

Community service program take place at university Mercu Buana is to improve the ability of prospective professional accountants to communicate well. This servise community activity follow by UMB students. This activity take place on class and running for 5 hours. The Instructure give them material of how to effort their communication skills and professionalism can be improved. Thus, this community service program can be seen as an effort to improving the ability of millennials accountant to hope their communication skills in a professional manner. Communication material consist of how to communicating with the millennial:

1. Learn to listen

Listen to another person, aren't just hearing the words that are said but taking in the entire moment noticing not only what is said, but how it is said, what is not said and most importantly, the body language of the speaker. All those elements combine to tell the full story. A study by the famed researcher, Albert Mehrabian found that only $\mathbf{7 \%}$ of what is communicated is done through the actual words used. Leaving an incredible $93 \%$ of the information conveyed to non-verbal forms of communication. By learning to truly listen to millennial employees, are conveying respect and letting them know that their thoughts and opinions matter which leads to a sense of loyalty.

\section{Short Communication}

Writing to communicate with millennial employees shorter is better. For instance, if writing an email to employees it is best to be direct, succinct and keep out unnecessary information.

3. Constructive and consistent with feedback.

Millennials are widely known to want consistent, regular feedback from their managers. Many managers 
cringe at the very thought. The feedback doesn't need to be extensive. Millennial employees want to know that they are moving in the right direction and a few constructive words, as their manager, can keep them going or help to avert a crisis. Managers who are consistently communicating constructive (both positive and negative) feedback tend to have teams that function at the highest levels of efficiency and productivity.

4. Don't make assumptions.

Assumptions tend to get in trouble, yet as humans, we make snap judgments all the time. According to the data, millennials stayed in their positions for 3.2 years versus the Generation X cohort at the same point in their career at 2.7 years.Assumptions in the workplace can be dangerous. At best, they keep from uniting as a team. At worst, they can drive wedges between colleagues and eventually bring down team morale.

5. Be honest about shortcomings.

Millennials, in particular, relate to our innate flaws. Millennials tend to relate transparency to trustworthiness make the levels of productivity increase.

The amazing effect that communication skills have in the workplace is that when communication is done well, it can make an incredible impact on any business situation. But when communication skills are lacking, that too, can have an incredible impact on any business situation. Without a solid foundation of good communication skills, companies will struggle to not only be productive and efficient, but also to be profitable. Good communication skills are the key to making everyone feel heard and respected.

The activity to improve the ability student to make communication used the step bellow :

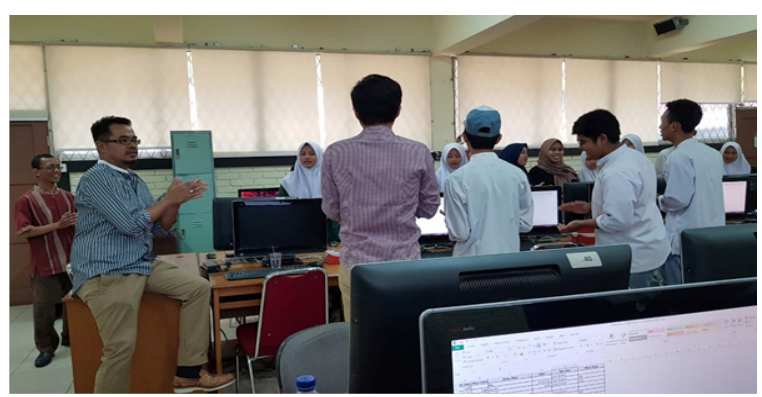

Figure 2. Actvity devide into groups

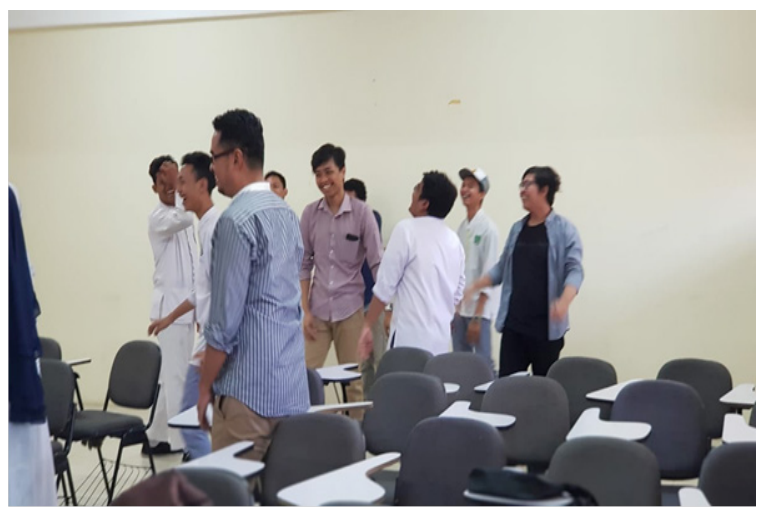

Figure 3. Activity for communication practise
Divide the group into teams of two until three students. Each team has one piece of paper and two pencils. When the leader starts the time (a two minute time limit is suggested), the team mates are solve the poblem an accountant between them, each of them will discuss how to solve with the step of activity. They are to write as quickly as possible.

This activity takes some time (appx. 40 minutes with 20 students), but the students have a lot of serious thiking with it and even those who are not exactly right will often be very close. It does a great job of illustrating how much information they get from nonverbal clues.

The students very antusiasme to participate in training activities that help the students to improve communication skills when there are problems in accounting. While the Millennial career expectations can be seen as a system of norms, values, and beliefs (Suchman, 1995) which characterize members of this new generation of accountants. Therefore, becomes important to hold the traning. This training will improve their communication skills for accounting students so that they can overcome the obstacles of communication as accountant professionals.

\section{CONCLUSIONS AND SUGGESTIONS}

\section{Conclusion}

The conclusions that can be drawn from the results of these community service activities with the theme of Improving Communication Skills for Millennial Accountants are:

1. PPM participants have fully discussed the problem of communication in solving problems Together with groups that have not yet met.

2. Training participants are happy and enthusiastic about the training. This can be seen from the familiarity between the participants who have not been known before to discuss the compilation given the problem.

3. Participants gain new knowledge, experience and skills through training, how to develop conversation skills.

4. This training is a provision for participants to continue to improve their skills in improving communication to be able to overcome problems and improve networking with other participants.

\section{Suggestion}

Suggestions proposed for further community service activities are that these community service activities can be carried out for a wider target area with a greater number of participants so that most melenial students especially students have good communication skills, especially for an accountant.

\section{REFERENCES}

Hartman, J. L., \& McCambridge, J. (2011). Optimizing Millennials' Communication Styles. Business Communication Quarterly, 74(1), 22-44.

Bonaparte, Y. (2018). The Millennials Acts in Finance. Available at SSRN 3103883. 
Krishnan, R. (2015). Management accountant-What ails thee?. Journal of Management Accounting Research, 27(1), 177-191.

Durocher, S., Bujaki, M., \& Brouard, F. (2016). Attracting millennials: Legitimacy management and bottom-up socialization processes within accounting firms. Critical perspectives on Accounting, 39, 1-24.
Deloitte Indonesia Perspectives ,(2019). Generasi Milenial dalam Industri 4.0: Berkah Bagi Sumber Daya Manusia Indonesia atau Ancaman? Edisi Pertama, September 2019.

http://www.republika.co.id/berita/koran/ inovasi/16/12/26/ois64613-mengenal-generasimillennial 